\title{
PERAN KEPALA MADRASAH SEBAGAI MOTIVATOR DAN INOVATOR DALAM UPAYA MENUJU KEPEMIMPINAN PENDIDIKAN EFEKTIF
}

\author{
Siti Wahyuni \\ Institut Agama Islam Tribakti Kediri
}

\begin{abstract}
Abstrak.
Kepala Madrasah sebagai pengatur sebuah lembaga pendidikan Islam mempunyai fungsi dan peran tersendiri untuk dapat menjalankan fungsi dan perannya dengan baik, maka seorang pemimpin harus mempunyai sifat-sifat kepemimpinan yang baik, ideal, bijaksana dan sangat bervariasi. Tulisan ini mengupas tentang hubungan kepala madrasah dengan teman sekerja, dengan atasan, pihak atasan, disiplin kerja, keamanan dalam bekerja, tugas-tugas yang dikerjakan (terutama yang menantang) tanggung jawab dalam bekerja, supervisi atau pembinaan dari pihak atasan. Peran Kepala Madrasah sebagai pemimpin lembaga pendidikan formal mempunyai peranan yang sangat penting dalam pemberdayaan tenaga pendidikan. Untuk itu kepemimpinannya diperlukan untuk membawa perubahan-perubahan konstruktif dalam program- program pengajaran sesuai dengan berbagai nilai dan tujuan pendidikan.
\end{abstract}

Kata Kunci : Kepala Madrasah, motivator, innovator, kepemimpinan efektif

\section{Pendahuluan}

Kepala Madarasah merupakan motor penggerak, penentu arah kebijakan sekolah, yang akan menentukan bagaimana tujuan-tujuan Madrasah dan pendidikan pada umumnya di realisasikan.

Dalam rangka melakukan peran dan fungsinya sebagai inovator, Kepala Madarasah harus memiliki strategi yang tepat untuk menjalani hubungan yang harmonis dengan lingkungan, mencari gagasan baru, mengintegrasikan setiap kegiatan, memberikan teladan kepada seluruh tenaga kependidikan di sekolah, dan mengembangkan model-model pembelajaran inovatif.

Kepala Madrasah sebagai motivator, tentunya harus memiliki strategi yang tepat juga untuk memberikan motivasi kepada para tenaga kependidikan dan melakukan berbagai tugas dan fungsinya.Motivasi ini dapat di tumbuhkan melalui pengaturan lingkungan fisik, pengaturan suasana kerja, disiplin, dorongan, penghargaan secara efektif dan penyediaan pusat sumber belajar melalui pengembangan pusat sumber belajar.

Akhlak islam yang diajarkan oleh Nabi Muhammad SAW memiliki sifat-sifat yang dapat dijadikan landasan bagi pengembangan profesionalisme seorang pemimpin dan melaksanakan kepemimpinannya ini dapat dilihat dari sifat-sifat Nabi yaitu sifat kejujuran (shidiq), sifat tanggung jawab (amanah), sifat komunikatif (tabligh), sifat cerdas (fathonah), bersikap positif (khusnudzon), sidiplin waktu dan menepati janji, bertindak efektif dan efisien, memberikan upah secara tepat dan cepat, memperbanyak silaturahmi.

\section{Peran Kepala Madrasah sebagai Motivator}

Sebagai motivator, kepala sekolah harus memiliki strategi yang tepat untuk memberikan motivasi kepada para tenaga kependidikan dalam melakukan berbagai tugas dan fungsinya. Motivasi ini dapat ditumbuhkan melalui pengaturan lingkungan fisik, pengaturan suasana kerja, disiplin, dorongan, penghargaan secara efektif, dan penyediaan pusat sumber belajar melalui pengembangan pusat sumber belajar. ${ }^{11}$

Memotivasi adalah memberi doronagn kepada guru-guru agar aktif bekerja menurut prosedur dan metode 
tertentu sehingga pekerjaan itu berjalan dengan lancar mencapai sasaran. Tugas memotivasi dan mengaktifkan ini bila dilengkapi dengn usaha mensejahterakan guru-guru, diyakini akan memberi hasil yang menggembirakan. Dan hal ini bisa dilaksanakan mengingat kesejahteraan itu sebagian dapat direalisasi melalui kegiatan-kegiatan memotivasi dan mengaktifkan seperti akan diuraikan pada bagian ini.

Sama halnya dengan uraian pada bagian memimpin, maka memotivasi, mengaktifkan, dan mensejahterakan ini pun tekanannya kepada guru-guru baik unutk mengajar di sekolah maupun di lapangan. Memotivasi dan mengaktifkan sangat diperlukan pada masa ini, mengingat ditenagarai bahwa semangat dan disiplin kerja belum tinggi secara merata di kalangan para pendidik.Tampaknya mereka belum begitu komit dengan pekerjaannya mendidik dan mengajar.

Teori Dua Faktor, mempergunakan dua macam factor untuk meningkatkan motivasi para guru, yaitu factor pemotivasi dan factor penghambat motivasi. Teori ini sudah dicoba di Jawa Timur ternyata memberi kandungan atau isi factor yang berbeda dengan aslinya dari dunia barat. Factor pemotivasi adalah :

1. Hubungan dengan teman sekerja.

2. Hubungan dengan atasan.

3. Kepemimpinan dari pihak atasan.

4. Disiplin kerja.

5. Keamanan dalam bekerja.

6. Tugas-tugas yang dikerjakan (terutama yang menantang)

7. Tanggung jawab dalam bekerja.

8. Supervisi atau pembinaan dari pihak atasan.

Sementara itu melalui analisis secara logis diketemukan factor penghambat motivasi sebagai berikut :

1. Gaji dan kesejahteraan lainnya.

2. Kebutuhan atau pemenuhan motivasi invidual.

3. Sarana bekerja.

Jadi bila kepala sekolah ingin memakai terori ini dalam memotivasi para guru, hendaklah kandungan atau butir- butir factor pemotivasi di atas ditingkatkan atau sering dilakukan dan butir-bitur factor penghambat usahakan terpenuhi.Kalau gaji tidak dapat dinaikkan oleh kepala sekolah, mungkin kesejahteraan mereka bisa diperbanyak sumbernya seperti diuraikan pada bagian berikut.Begitu pula motivasi/ kebutuhan individual perlu diteliti satu persatu untuk diupayakan dipenuhi.Dan sarana bekerja perlu pula diperbaiki.

Usaha lain yang dapat dilakukan kepala sekolah dalam rangka memotivasi, mengaktifkan, dan sekaligus meningkatkan kesejahteraan para guru adalah dengan mengadakan kompetesi sehat. Kompetesi ini dilakukan antara lain dengan cara :

1. Memberi pujian dan penghargaan kepada guru-guru yang berprestasi, yang dilakukan di depan umum, misalnya pada waktu upacara.

2. Meningkatkan kerja nyata para siswa baik dalam kuantitas, kualitas, maupun ragamnya dengan tidak merugikan proses belajar mereka. Bagi kelas, kelompok siswa, dan guru pembinanya yang berhasil diberi penghargaan atau insentif khusus.

3. Guru-guru pengantar yang membawahi kelompok-kelompok atau individu siswa yang praktek di perusahaan juga diberi insentif yang memadai sesuai dengan tingkat kemajuan kelompok atau siswa yang diasuhnya. Guru-guru ini walaupun tidak ikut menjadi instruktur, tetapi ia ikut bertanggung jawab akan kemajuan atau kemunduran praktek siswanya.

4. Mempertimbangkan hasil-hasil penilaian warga masyarakat, orang tua siswa, dan pengusaha terhadap sekolah, khususnya terhadap guruguru sebagai pelaksana pengajaran. Hasil penilaian ini perlu diumumkan di depan umum.

5. Bila perlu mengundang warga masyarakat, ketika mengumumkan hasil-hasil kompetisi diatas. Hadiah atau insentifnya di serahkan oleh tokoh masyarakat.Hasil-hasil kompetisi ini bisa dijadikan bahan pertimbangan dalam mengisi DP3. 
Dengan cara ini sekaligus kesejahteraan materi para guru dapat ditingkatkan, manakala hasil-hasil penjualan karya nyata bisa memadai. Kesejahteraan personalia sekolah, khsususnya guru-guru akan semakin meningkat, bila sekolah bersama warga masyarakat dapat membentuk beberapa usaha bersama.

Demikianlah cara-cara kepala sekolah memotivasi, mengaktifkan, dan mensejahterakan personalia sekolah. Bila hal ini bisa diwujudkan perilaku-perilaku individu secara perlahan-perlahan dapat diarahkan menjadi perilaku organisasi, suatu perilaku kelompok yang mengarah kepada pencapaian tujuan pendidikan.

\section{Peran Kepala Madrasah sebagai Inovator}

Dalam rangka melakukan peran dan fungsinya sebagai innovator, kepala sekolah harus memiliki strategi yang tepat untuk menjalani hubungan yang harmonis dengan lingkungan, mencari gagasan baru, mengintegrasikan setiap kegiatan, memberikan teladan kepada seluruh tenaga kependidikan di sekolah, dan mengembangkan model-model pembelajaran inovatif.

Kepala madrasah sebagai innovator akan tercermin dari cara-cara ia melakukan pekerjaannya secara kontruktif, kreatif, delegatif, integrative, rasional dan obyektif, pragmatis, keteladanan, disiplin, serta adabtabel dan fleksibel. ${ }^{2}$ Konstruktif, dimaksudkan bahwa dalam meningkatkan profesionalisme tenaga kependidikan di madrasah, kepala madrasah harus berusaha memberikan saran, mendorong dan membina setiap tenaga kependidikan agar dapat berkembang secara optimal dalam melakukan tugas-tugas yang diembannya.Kreatif, dimaksudkan bahwa dalam meningkatkan profesionalisme tenaga kependidikan di madrasah, kepala madrasah harus berusaha mencari gagasan dan cara-cara baru dalam melaksanakan tugasnya.Delegatif, dimaksudkan bahwa dalam meningkatkan profesionalisme tenaga kependidikan di madrasah, kepala madrasah harus berusaha mendelegasikan tugas kepada tenaga kependidikan sesuai dengan deskripsi tugas, jabatan serta kemampuan masing-masing.Integrative, dimaksudkan bahwa dalam meningkatkan profesionalisme tenaga kependidikan di madasah, kepala madrasah harus berusaha mengintegrasikan semua kegiatan, sehingga dapat menghasilkan sinergi untuk dapat mencapai tujuan madrasah secara efektif, efisien, dan produktif.Rasional dan obyektif, dimaksudkan bahwa dalam meningkatkan profesionalisme tenaga kependidikan di madrasah, kepala madrasah harus berusaha bertindak berdasarkan pertimbangan rasio dan obyektif.Pragmatis, dimaksudkan bahwa dalam meningkatkan profesionalisme tenaga kependidikan di madrasah, kepala madrasah harus berusaha menetapkan kegiatan atau target berdasarkan kondisi dan kemampuan nyata yang dimiliki oleh setiap tenaga kependidikan, serta kemampuan yang dimiliki oleh madrasah.Keteladanan, dimaksudkan bahwa dalam meningkatkan profesionalisme tenaga kependidikan di madrasah, kepala madrasah harus berusaha memberikan teladan dan contoh yang baik.Adabtabel dan fleksibel, dimaksudkan bahwa dalam meningkatkan profesionalisme tenaga kependidikan di madrasah, kepala madrasah harus mampu beradaptasi dan fleksibel dalam menghadapi situasi baru, serta berusaha menciptakan situasi kerja yang menyenangkan dan memudahkan para tenaga kependidikan untuk beradaptasi dalam melaksanakan tugasnya. ${ }^{3}$

\section{Sasaran Inovasi}

Kepala madrasah sebagai innovator harus mampu mencari, menemukan, dan melaksanakan berbagai pembaharuan di madrasah.Gagasan baru tersebut misalnya moving class.Moving class adalah mengubah strategi pembelajaran dari pola kelas tetap menjadi kelas bidang studi, sehingga setiap bidang studi memiliki kelas 
tersendiri, yaitu dilengkapi dengan alat peraga dan alat-alat lainnya.Moving class ini bisa dipadukan dengan pembelajaran terpadu, sehingga dalam suatu laboratorium bidang studi dapat dijaga oleh beberapa orang guru (fasilitator), yang bertugas memberikan kemudahan kepada peserta didik dalam belajar ${ }^{4}$.Hal senada juga dikatakan oleh Sagala, bahwa untuk mengoptimalkan kulaitas pembelajaran kegiatan belajar mengajar di kelas, maka salah satu sistem pendidikan yang diterapkan adalah moving class (kelas berjalan). Moving class adalah suatu model pembelajaran yang diciptakan untuk belajar aktif.

\section{Kepemimpinan Kepala Madrasah Menuju Kepemimpinan Efektif}

Pemimpin yang efektif adalah pemimpin yang mengunakan gaya dapat mewujudkan sasarannya, misalnya dengan mendelagasikan tugas, mengadakan komunikasi yang efektif, memotivasi bawahannya, melaksanakan control dan seterusnya ${ }^{5}$. Kepemimpinan yang efektif merupakan kepemimpinan yang mampu menggerakkan pengikutnya untuk mencapai tujuan yang telah dirumuskan bersama.

Stidaknya terdapat 4 gaya dalam kepemimpinan sebagai ukuran efektifitas kepemimpinan, yaitu 1) gaya kepemimpinan yang tidak memperhatikan hasil produksi dan juga tidak memperhatikan kekompakan anggotanya, 2) gaya kepemimpinan yang sangat memperhatikan hasil produksi tatapi rendah perhatiannya pada kekompakan anggota, 3) gaya kepemimpinan yang sangat memperhatikan kekompakan anggota tetapi rendah perhatiannya pada hasil produksi, dan 4) gaya kepemimpinan yang sangat memperhatikan hasil produksi sekaligus sangat memperhatikan kekompakan anggota. ${ }^{6}$ Sementara hasil

4 Ibid., h. 119

5 Usman, Manajemen Teori, h. 293.

6 Zaenal Arifin. (2016). Efektifitas Kepemimpinan Lembaga Pendidikan Islam di Pesantren. Jurnal Pemikiran Keislaman, 27(1), 40 64. https://doi.org/10.33367/tribakti.v27i1.258 kajian terhadap beberapa referensi menemukan 6 karakteristik kepemimpinan yang baik.

Dalam upaya menuju kepemimpinan pendidikan Islam secara efektif, setidaknya para pemimpin harus dilatih sesuai dengan corak pendekatan perilaku. Latihan-latihan itu dapat diwujudkan melalui ${ }^{7}$ :

Pertama, meneladani seorang tokoh (Al Qudwah), Yaitu melalui magang dengan seorang pemimpin yang berpengaruh, melihat sikap dan perilakunya. Tetapi dengan metode seperti itu akan timbul dua catatan, pertama, bahwa kesalahan dapat berpindah secara terselubung yang kadang dapat membunuh atau menghancurkan, karena ketidak mampuan sosok yang dilatih ini merupakan tanggung jawab sang tokoh. Kedua, merealisir apa yang dinamakan personifikasi, yang merupakan penjelmaan potret pemimpinnya. Oleh karena itu, kita tidak dikatakan telah mendidik seorang pemimpin baru, tetapi itu seperti seseorang yang berhenti berjalan untuk beberapa saat dan tidak dapat melangkah walau satu langkah serta tidak tahu penyebabnya. Karena kita hanya menjiplak seorang pemimpin teladan secara bulat dengan seluruh aspek positif dan negatifnya.

Kedua, Latihan Bersikap, Yaitu melalui pemberian tanggung jawab pada seseorang yang dilatih untuk memimpin sebuah diskusi, mengurus kepanitiaan, mengelola pekerjaan atau melaksanakan sebuah tugas penting.Ia dipantau oleh panitia khusus yang akan mengevaluasi, memperbaiki atau mempersiapkan kader pemimpin tersebut untuk mengikuti kursus kepemimpinan. Sehingga dari upaya itu setidaknya ia akan dijamin dapat merealisasikan dua hal :

a. Memiliki kemahiran memimpin.

b. Mampu mentranfer informasi.

Dari Ath-Thabrani, seseorang berkata : Rasulullah SAW menugaskan seorang sahabat untuk memimpin sebuah

7 Jamal Madhi, Menjadi Pemimpin yang Efektif dan Berpengaruh Tinjauan Manajemen Kepemimpinan Islam, terj. Anang Syafruddin dan Ahmaf Fauzan (Bandung: PT. Syaamil Cipta Media, 2004), h. 12 
pasukan kavaleri. Setelah selesai ia kembali dan Rasullullah SAW bertanya kepadanya : "Bagaimana engkau mendapatkan kepemimpinan itu?" Ia berkata : "Aku seperti bagian kaum. Jika aku menaiki kendaraanku, mereka ikut naik, dan jika aku turun mereka ikut turun". Maka Nabi Muhammad SAW bersabda:"Demi Allah, aku tidak akan mau lagi bekerja (sebagai pemimpin)untukmu atau orang lain". Lalu tersenyumlah Rasulullah SAW hingga terlihat gerahamnya. Dalam riwayat lain lelaki itu adalah Miqdad bin Al-Aswad r.a. (Al-Haitsami:5/20)

Hadits ini menunjukkan bahwa Rasullullah SAW selalu memotivasi para sahabatnya untuk memimpin melalui sikap dan beliau terus mengontrol perkembangannya. Kepemimpinan harus dilakukan dengan penuh kesabaran dan dimulai dari diri sendiri, mulai dari hal yang terkecil dan mulai saat ini. Pemimpin hendaknya jangan menunda suatu pekerjaan karena hal itu akan mengakibakan terbengkalainya suatu pekerjaan.

\section{Kepemimpinan dalam Manajemen Pendidikan Islam}

Dalam bahasa Arab, kata yang sering dihubungkan dengan kepemimpinan adalah ra'in yang diambil dari hadis Nabi SAW, kullukum ra'in wa kullukum mas'ulun 'an ra'iyyatihi, setiap kamu adalah pemimpin, dan setiap kamu bertanggungjawab atas kepemimpinanmu. $R a^{\prime}$ in arti asalnya adalah gembala. Seorang pemimpin ibarat seorang pengembala yang harus mebawa ternaknya ke padang rumput dan menjaganya agar tidak diserang serigala.

Adapun ra'iyyah berarti rakyat. Jadi, seorang pemimpin pasti mempertanggungjawabkan kepemimpinannya di hadapan rakyat.Selain kata $r a^{\prime} i n$, kata $r a$ 'is juga sering dipakai yang berhubungan dengan kata $r a$ 's, artinya kepala.Ada yang menggunakan kata sa'is yang berarti pengendali kuda, artinya seorang pemimpin adalah seorang yang mampu mengendalikan anggotanya.Sa'is memiliki akar kata yang sama dengan siasat atau strategi. Untuk itu, dalam memimpin diperlukan strategi.

Ada pula yang mengartikan pemimpin dengan kata imam, yang berarti di depan. Kata ini memiliki akar yang sama dengan umm, yang berarti ibu. Seorang imam atau pemimpin harus memiliki sifat seorang ibu.Penuh kasih sayang dalam membimbing dan mengendalikan umat.Ada kaitan antara imam, umm, dan umat.

Islam memberikan posisi terhormat bagi para pemimpin. Bahkan dalam AlQur'an sebuah doa agar kita menjadi pemimpin, sebagaimana dinyatakan dalam surat Al-Furqan ayat 74 : yang artinya "Dan orang-orang yang berkata,'Ya Tuhan kami, anugrahkanlah kepada kami pasangan kami dan keturunan kami sebagai penyenang hati (kami), dan jadikanlah kami imam bagi orang-orang yang bertaqwa'."(QS. Al-Furqan : 74)

Dalam manajemen pendidikan Isalam, pelaksanaan kepemimpinan dipengaruhi oleh berbagai macam factor. Menurut H. Jodeph Reitz (1981) yang dikutip Nanang Fattah, faktor-faktor tersebut adalah sebagai berikut :

1. Kepribadian (personality), pengalaman masa lalu dan harapan pemimpin. Hal ini mencakup nilai-nilai latar belakang dan pengalamannya akan mempengaruhi pilihan dalam gaya kepemimpinan. Dalam manajemen pendidikan Islam, kepribadian utama seorang pemimpin adalah keteladanannya yang patut ditiru oleh semua bawahannya.

2. Harapan dan perilaku atasan berkaitan dengan tujuan kepemimpinan, yakni saling menasihati dalam kebenaran dan kesabaran.

3. Karakeristik, harapan, dan perilaku bawahan mempengaruhi terhadap gaya kepemimpinan yang terapkan. Gaya paling ideal adalah gaya kepemimpinan Rasulullah SAW, yang selalu menjaga sikap disiplin, professional, pengasih, penyayang, dan mengembangkan kerjasama. 
4. Kebutuhan tugas, setiap tugas bawahan juga akan mempengaruhi gaya pemimpin. Bawahan harus taat kepada atasan yang selalu berada di jalan Allah SWT.

5. Iklim dan kebijakan organisasi mempengaruhi harapan dan perilaku bawahan.

6. Harapan dan perilaku rekan organisasi didikat oleh tali persaudaraan.

\section{Kecerdasan Emosional Kepala Madrasah dalam Pengendalian Konflik di Madrasah}

Kepala madrasah merupakan figure utama dalam suatu lembaga pendidikan Islam, terutama di madrasah. Tanpa adanya kepala madrasah, maka segala kegiatan yang ada di dalam madrasah tidak dapat berjalan dengan baik.Maka dari itu, kepala madrasah harus mampu menjalankan peran dan fungsinya dengan baik, supaya kegiatan madrasah dapat berjalan secara efektif dan efisien.Peran dan fungsi kepala madrasah antar lain, sebagai pemimpin, sebagai edukator, sebagai administrator, sebagai supervisor, sebagai innovator, sebagai manajer dan lain sebagainya.

Kepala madrasah diharapkan memiliki kecerdasan emosional yang cukup tinggi agar mampu melakukan kepemimpinannya dengan efektif, termasuk didalamnya mengendalikan konflik yang ada di madrasah tersebut.Kecerdasan emosional tertentu diperoleh dari pengalaman khusus, kemudian diinternalisasikan sebagai suatu kriteria yang berharga.Menurut teori kepemimpinan, kecerdasan emosional merupakan salah satu kriteria keberhasilan pemimpin dalam mengelola organisasinya.

Fungsi kecerdasan emosional dalam kepemimpinan adalah membantu pemimpin memahami eksistensinya dan merasakan keberadaan orang-orang.Untuk dapat berhasil, pemimpin perlu mempertimbangkan dan menilai secara luas dan cermat faktor, sifat, atau ciri pemimpin, syarat kualitas pribadi, pendidikan, dan latihan, kesempatan untuk berkembang, kondisi kerja, kompetensi dan prestasi.

Kecerdasan emosional mempunyai arti yang penting dalam kepemimpinan.Bantuan penelitian atau teori pada kepemimpinan dalam mengklarifikasi kecerdasan emosional untukmengelola organisasi dalam mencapai keberhasilan adalah sangat penting8. Seorang kepala sekolah yang mempunyai kecerdasan emosional yang tinggi akan mampu mengatasi konflik, kesenjangan yang perlu dijembatani atau diisi,melihat hubungan tersembunyi yang menjanjikan peluang, dan menempuh interaksi gelap dan misterius yang secara pertimbangan paling bisa membuahkan emas secara lebih siap, cekatan dan cepat dibandingkan orang lain.

Seorang kepala madrasah yang memiliki kecerdasan emosional yang tinggi akan peka terhadap konflik yang terjadi sehingga berusaha menyelesaikan konflik itu ketika baru memasuki tahap pertma yakni tahap laten yang masih berupa perbedaan baik karena factor individu, organisasi maupun lingkungan, agar konflik bisa dibendung secepatnya sehingga masih relative mudah penyelesaiannya, dan terhindar dari benturan yang berlarut-larut. Penyelesaian pada tahap perbedaan ini meskipun tidak termasuk upaya preventif tetapi sebagai penyelesaian yang cepat tanggap yang memiliki pengaruh signifikan dalam menekan terjadinya konflik yang sesungguhnya.

Dalam rangka menyelesaikan konflik dibutuhkan pendekatan-pendekatan psikologis karena menyangkut perasaan, kesadaran,, dan suasan batin seseorang yang sedang berkonflik. Oleh karena itu, menurut Djohar, cara kreatif dalam menyelesaikan konflik biasanya memerlukakn waktu yang lama, kesabaran, kedewasaan emosional, tetapi menghasilkan win-win solution dan

8 Rohiat, Kecerdasan Emosional Kepemimpinan Kepala Sekolah (Bandung: Refika Abditama, 2008), h. 54. 
menghasilkan kedamaian ${ }^{9}$. Suatu hasil yang memuaskan semua pihak yang diharapkan bersama dalam setiap penyelesaian konflik, sehingga konflik benar- benar bisa teratasi secara tuntas.Maka disinilah kecerdasan emosional kepala madrasah diperlukan. Disamping itu, seorang kepala madrasah yang mempunyai kecerdasan emosional yang cukup tinggi akan mampu berkomunikasi yang efektif dengan para anggota atau bawahannya, sehinggadapat mencegah konflik dan memahami masalah masing-masing anggota. Kepala madrasah tidak boleh menutup diridari pergaulan dengan bawahannya, namun juga tidak melewati batas, sehingga kewibawaannya sebagai kepala madrasah akan hilang dan menjadi tidak dihormati lagi.

Kepala madrasah yang mempunyai kecerdasan emosional yang cukup tinggi akan mampu menanggapi semua tekanan pekerjaan yang ditujukan kepadanya. Ia akan lebih arif dalam memahami kehidupan dn situasi yang berlangsung juga konflik yang terjadi. Di smaping itu, kepala madrasah tersebut akan mampu mempunyai dan mengembangkan intensionalitas ke arah yang lebih baik.

Cara atau teknik yang diterapkan oleh kepala madrasah dalam mengendalikan konflik yang terjadi di madrasahnya adalah dengan menggunakan kasih sayang.Sebuah konflik yang terjadi pastilah dapat diredakan dengan kasih sayang yang dilakukan oleh kepala madrasah. Dengan kasih sayang, maka kepala madrasah akan mampu mengarahkan dengan pelan-pelan orang yang terlibat pada konflik.

Dengan memahami cara penyelesaian konflik tersebut, dan berbekal kecerdasan emosional yang cukup memadai, maka kepala madrasah akan mampu mengendalikan dan menyelesaikan konflik yang ada dalam madrasah tersebut. ${ }^{10}$

9 Djohar, Pendidikan Strategik Alternatif untuk Pendidikan Masa Depan (Yogyakarta: LESFI, 2003), h. 106.

10 Panduan, h. 189-190

\section{Kesimpulam}

Ajaran Islam sebagai agama universal sangat kaya akan pesan-pesan yang mendidik bagi muslim unutk menjadi umat terbaik, menjadi khalifah, yang mengatur dengan baik bumi dan isinya. Pesan-pesan itu sangat mendorong kepads setiap muslim untuk berbuat dan bekerja secara professional, yakni bekerja dengan benar, optimal, jujur, disiplin dan tekun ${ }^{27}$.

Akhlak Islam yang diajarakan oleh Nabi Muhammad SAW, memiliki sifat-sifat yang dapat dijadikan landasan bagi pengembangan profesionalisme seorang pemimpin dalam melaksanakan kepemimpinannya. Ini dapat dilihat pada pengertian sifat-sifat akhlak Nabi, yaitu : ${ }^{28}$

1. Sifat kejujuran (shidiq)

Kejujuran ini menjadi salah satu dasar yang paling penting untuk membangun seorang pemimpin yang baik.Hampir semua usaha yang dikerjakan bersama menjadi lancar, karena adanya kejujuran.Oleh karena itu kejujuran menjadi sifat wajib bagi Rasulullah SAW.Dan sifat ini pula yang selalu diajarkan oleh Islam melalui Al-Qur'an dan sunah Nabi.Kegiatan yang dikembangkan di dunia organisasi, perusahaan, dan lembaga modern saat ini sangat ditentukan oleh kejujuran.Begitu juga tegaknya Negara sangat ditentukan oleh sikap jujur para pemimpinnya.Ketika para pemimpinnya tidak jujr dan korup, maka Negara itu menghadapi problem nasional yang sangat berat, dan sangat sulit untuk membangkitkan kembali.

2. Sifat tanggung jawab (amanah)

Sikap tanggung jawab juga merupakan sifat akhlak yang sangat diperlukan unutk membangun profesionalisme. Suatu perusahaan/ organisasi/ lembaga apapun pasti akan hancur bila orang-orang yang terlibat didalamnya tidak amanah.

3. Sifat komunikatif (tabligh)

Salah satu ciri professional adalah sikap komunikatif dan transparan. Dengan sikap komunikatif, seorang penanggung jawab suatu pekerjaan akan dapat terjalin kerjasama dengan orang lain lebih lancar. Ia dapat juga meyakinkan rekanannya 
untuk melakukan kerjasama atau melaksanakan visi dan misi yang disampaikan. Sementara dengan sikap transparan. Kepemimpinan di akses semua pihak tidak ada kecurigaan, sehingga semua masyarakat anggotanya dan rekan kerjasamanya akan memberikan apresiasi yang tinggi kepada kepemimpinannya. Dengan begitu, perjalanan sebuah organisasi lebih lancar, serta mendapat dukungan penuh dari berbagai pihak.

4. Sifat cerdas (fathanah)

Dengan kecerdasannya seorang professional akan dapat melihat dan menangkap peluang dengan cepat dan tepat. Dalam sebuah organisasi, kepemimpinan yang cerdas akan cepat dan tepat dalam memahami problematika yang ada di lembaganya. Ia akan cepat memahami aspirasi anggotanya, sehingga setiap peluang dapat segera dimanfaatkan secara optimal dan problem dapat dipecahkan dengan cepat dan tepat sasaran.

5. Bersikap positif dan bersikap positif (khusnudzan)

Berfikir positif akan mendorong setiap orang melaksanakan tugas-tugasnya lebih baik. Hal ini disebabkan dengan bersikap dan berfikir positif mendorong seseorang untuk berfikir jernih dalam menghadapi setiap masalah.Khusnudzan tersebut, tidak saja ditujukan kepada sesama kawan dalam bekerja, tetapi yang paling utama adalah bersikap dan bersikap positif kepada Allah SWT. Dengan pemikiran tersebut, seseorang akan bersikap objektif dan optimistic. Apabila ia berhasil dalam usahanya tidak menjadi sombong dan lupa diri, dan apabila gagal tidak mudah putus asa, dan menyalahkan orang lain. Sukses dan gagal merupakan pelajaran yang harus diambil untuk menghadapi masa depan yang lebih baik, dengan selalu bertawakal kepada Allah SWT.

6. Memperbanyak shilaturahim

Dalam Islam kebiasaan shilaturahim merupakan bagian dari tanda-tanda keimanan.Namun dalam dunia profesi, shilaturahim sering dijumpai dalam bentuk tradisi lobi. Dalam tradisi ini akan terjadi saling belajar.

7. Disiplin waktu dan menepati janji

Begitu pentingnya disiplin waktu, $\mathrm{Al}$ Qur'an menegaskan makna waktu bagi kehidupan manusia.Sebagai manusia yang telah menjadi seorang pemimpin wajib menghargai dan menggunakan waktunya dengan sebaik mungkin.

8. Bertindak efektif dan efisien

Bertindak efektif artinya merencanakan, mengerjakan dan mengevaluasi sebuah kegiatan dengan tepat sasaran.Sedangkan efisien adalah penggunaan fasilitas kerja dengan cukup, tidak boros dan memenuhi sasaran, juga melakukan sesuatu yang memang diperlukan dan berguna.Islam sangat menganjurkan sikap efektif dan efisien.

9. Memberikan upah secara tepat dan cepat

Ini sesuai dengan hadits Nabi, yang mengatakan berikan upah kadarnya, akan mendorong seseorang pekerja atau pegawai dapat memenuhi kebutuhan diri dan keluarganya secara tepat pula. Sementara apabila upah ditunda, seorang pegawai akan bermalas-malas karena dia harus memikirkan beban kebutuhannya dan merasa karya-karyanya tidak di hargai secara memadai.

\section{Daftar Pustaka}

Arifin, Z. (2016). Efektifitas Kepemimpinan Lembaga Pendidikan Islam di Pesantren. Jurnal Pemikiran Keislaman, 27(1), $40 \sim 64$. https://doi.org/10.33367/tribakti.v2 7i1.258

Danim, Sudarwan. Kepemimpinan Pendidikan: Kepemimpinan Jenius (IQ + EQ), Etika, Perilaku Motivasional, dan Mitos. Bandung: Alfabeta, 2010.

Djohar.Pendidikan Strategik Alternatif untuk Pendidikan Masa Depan. Yogyakarta: LESFI, 1993.

Hanson, E. Mark. Educational Administration and Organizational Bekairor. Boston: Allyn and Bacon, 1990. 
Madhi, Jamal.Menjadi Pemimpin yang Efektif dan Berpengaruh Tinjauan Manajemen Kepemimpinan Islam, terj.Anang Syafruddin dan Ahmad Fauzan. Bandung: PT. Syaamil Cipta Media, 2004.

Mulyasa, E. Menjadi Kepala Sekolah Proffesional: dalam Konteks Menyukseskan MBS dan KBK. Bandung: Remaja Rosdakarya, 2006.

Owens, Robert G. Organizational Behavior in Education. Boston: Allyn and Bacon, 1991.

Panduan Manajemen Sekolah, ttp: Departemen Pendidikan dan Kebudayaan Direktorat Jendral Pendidikan Dasar dan Menengah Direktorat Pendidikan Menengah Umum, 1998.

Qomar, Mujamil. Manajemen Pendidikan Islam: Strategi Baru Pengelolaan Lembaga Pendidikan Islam. Jakarta: Erlangga, 2008.

Rahim, Afzalur. Managing Conflict in Organizations. New York: Praeger, 1976

Rohiat, Kecerdasan Emosional Kepemimpinan Kepala Sekolah. Bandung: Refika Abditama, 2008.

S., D. Sudjana.Manajemen Program Ilmu Pendidikan untuk Pendidikan Luar Sekolah dan Pengembangan Sumber Daya Manusia. Bandung: Falah Production, 2000.

Usman, Husaini. Manajemen Teori, Praktik dan Riset Pendidikan. Jakarta: Bumi Aksara, 2009.

Wahjosumidjo. Kepemimpinan Kepala Sekolah. Jakarta: PT Raja Grafindo Persada, 2005 


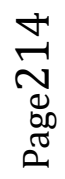

